\title{
Analisis gaya belajar VAK pada pembelajaran daring terhadap minat belajar siswa
}

\author{
Nilam Cahya Ritonga, Indah Fitriah Rahma \\ Pendidikan Matematika, Fakultas Keguruan dan Ilmu Pendidikan \\ Universitas Labuhanbatu \\ Jl. Sisingamangaraja No. 126 Bakaran Batu, Rantauprapat, Sumatera Utara, Indonesia \\ *nilamritonga04@gmail.com
}

Received: 01 Maret 2021; Accepted: o9 Juni 2021 ; Published: 30 Juni 2021

\begin{abstract}
Abstrak
Penelitian ini termasuk pada penelian deskriptif kualitatif. Tujuan dilakukannya penelitian ini untuk menganalisis gaya belajar VAK yang dapat menimbulkan minat belajar siswa pada pembelajaran daring. Subjek penelitian yaitu siswa sebanyak 36 orang yang berasal melalui SMA di Kota Rantauprapat. Instrumen dalam kajian ini berupa angket/kuesioner, interviu, observasi dan dokumentasi. Hasil kajian yang didapat memperlihatkan bila gaya belajar sangat berpengaruh terhadap minat belajar siswa dengan jumlah presentase peserta didik yang mempunyai gaya belajar visual 64\%, sedangkan auditori sebanyak 25\% dan kinestik 11\%. Dengan demikian, hasil kajian menjelaskan jika murid kelas XII yang mengikuti pembelajaran daring cenderung memiliki gaya belajar visual. Hal ini dilihat dari banyak nya siswa mengerjakan tugas dari guru ketika proses belajar mengajar mempergunakan gaya belajar visual.
\end{abstract}

Kata kunci: Gaya belajar, Pembelajaran daring, Minat belajar

\begin{abstract}
This research is included in qualitative descriptive research. The purpose of this research is to analyze VAK learning styles that can generate student interest in learning online. Research subject were 36 people who come from one of the senior high schools in the city of Rantauprapat. The instrument in this study was a questionnaire, interviews, observation and documentation. The results obtained indicate that the learning style is very influential on students interest in learning with the number of student presentations who have a visual learning style of $64 \%$, while the auditory is $25 \%$ and $11 \%$ kinesthetic. So from the results of this study it can be concluded that class XII students who take online learning tend to have a visual learning style.
\end{abstract}

Keywords: Learning styles, Online learning, Learning interests 


\section{PENDAHULUAN}

Saat ini wabah covid-19 telah menjajah manusia, tak hanya di Indonesia saja, bahkan saat ini di seluruh dunia tengah mengalami krisis kesehatan (Handarini ; Wulandari, 2020). Awalnya wabah ini hanya berdampak pada perekonomian saja, namun sekarang sudah berdampak kepada seluruh aktivitas. Sehingga seluruh aktivitas manusia dibatasi, salah satunya adalah kegiatan belajar mengajar disekolah. Belajar merupakan suatu hal yang tidak lagi asing dikehidupan manusia yang tidak terlepas dari pendidikan dan kewajiban sekolah (Laana, 2021).

Seorang guru harus memiliki ide bagaimana melakukan kegiatan belajar mengajar yang benar-benar tepat dengan situasi saat ini, seperti dengan melakukan perubahan pada sistem pembelajaran menjadi pembelajaran daring (Wiranti \& Sutriyani, 2020). Ditengah pandemi ini penggunakan teknologi informasi sangat krusial pada pelaksanaan kegiatan belajar mengajar secara daring (Sutriyani, 2020). Pembelajaran dengan sistem daring ini telah menghadirkan model pembelajaran yang baru di Indonesia (khabiburrokhman, ali, 2020)

Pembelajaran daring adalah proses belajar mengajar dengan cara mempergunakan jaringan internet beraksebilitas, terkoneksi, dan fleksibiitas, serta kapabilitas dalam melahirkan bermacam interaksi pembelajaran (Sadikin \& Hamidah, 2020).

Kegiatan belajar mengajar secara daring merupakan aktivitas belajar mengajar alternatif dilakukan selama pandemi dengan tidak serta merta harus bertemu muka antara siswa dan guru (Yanti, ; Nindisari, 2020). Pembelajaran secara daring adalah proses belajar mengajar yang dilaksanakan secara virtual dengan menggunakan aplikasi (Syarifudin, 2020).

Kegiatan belajar mengajar daring terbagi menjadi dua tipe, yaitu Syinchronous (pembelajaran daring pada waktu bersamaan) seperti tatap muka secara langsung dengan menggunakan aplikasi seperti zoom dan
Asynchronous (pembelajaran daring pada waktu tidak bersamaan) seperti guru memberi tugas dengan batas waktu yang telah ditentukan sehingga siswa diberikan waktu yang bebas untuk mengerjakannya (Hartanto, 2016).

Proses pembelajaran merupakan suatu perihal yang dapat memastikan hasil maupun prestasi dari murid. Kesesuaian model pembelajaran yang digunakan dengan materi merupakan hal yang sangat perlu untuk ditinjau oleh seorang pendidik sebelum melangsungkan kegiatan pembelajaran (Yulianci1 \& Nurjumiati1; Asriyadin1, 2020). Dalam mendesain suatu pembelajaran, seorang tenaga pendidik harus mampu memahami dengan baik bagaimana gaya belajar siswa.

Gaya belajar ialah keistimewaan bagi tiap individu selama menelaah pembelajaran, yang meliputi metode belajar visual, auditorial, dan kinestik. Gaya belajar visual ialah metode pembelajaran yang berfokus di penglihatan, pengamatan, ataupun pandangan. Metode pembelajaran auditorial ialah metode pembelajaran yang berfokus ke indera pendengar. Gaya belajar kinestik ialah metode belajar yang berfokus pada gerakan (Papilaya \& Huliselan, 2016)

Gaya belajar yang tepat merupakan aspek penting dari kesuksesan murid selama belajar (Bire, \& Bire, 2014). Penerapan model pembelajaran yang benar-benar sesuai dapat mendorong tumbuhnya rasa senang pada diri siswa dalam belajar (Rahmawati, 2017). Tidak akan ada pelajaran yang sulit jika setiap siswa mampu memahami informasi atau materi yang diberikan sesuai dengan gaya belajar yang dimilikinya.

Adanya penerapan proses belajar dengan metode jarak jauh membuat setiap siswa membutuhkan waktu untuk menyesuaikan diri karena berhadapan dengan dinamika yang turut berpengaruh pada minat belajarnya (Purwanto $\mathrm{dkk}, 2020$ ). 
Minat merupakan sumber motivasi yang mampu menggerakkan hati seseorang untuk mengerjakan sesuatu sesuai dengan apa yang dikehendakinya. Minat merupakan sebuah rasa suka atau keinginan yang tinggi atas sesuatu yang dimiliki oleh seseorang yang dipandang mampu memberikan kelebihan dan rasa puas bagi diri, maka memicu seseorang untuk terlibat pada aktivitas tersebut tanpa menunggu pihak lain meminta (Hayati, 2015). Secara garis besar, minat bisa muncul sebab motivasi yang asalnya dari diri sendiri, tetapi mayoritas siswa bersemangat hanya karena mendengarkan motivasi dari seseorang (Asikin, 2017).

Munculnya minat pada diri individu terklasifikasikan dalam dua macam, terdiri atas minat dari diri sendiri. Minat yang berasal akibat pengaruh dari luar dirinya disebabkan perkembangan individu tersebut (Laana \& Sondopen, 2018)

Setelah peneliti mengobservasi secara langsung dan melakukan interview ke beberapa tenaga pendidik di lembaga kependidikan tersebut, ditemukan permasalahan rendahnya minat belajar siswa selama proses pembelajaran secara daring diterapkan. Rendahnya minat belajar siswa tersebut disebabkan oleh beberapa hal, diantaranya terletak pada gaya belajar murid. Berdasar penjelasan tersebut, peneliti memiliki ketertarikan mengkaji dengan judul. "Analisis Gaya Belajar VAK Pada Pembelajaran Daring Terhadap Minat Belajar Siswa."

\section{METODE}

Kajian yang dilakukan tergolong penelitian deskriptif kualitatif. Kajian yang dilakukan bertujuan untuk menganalisis dan menggambarkan suatu kondisi dari setiap data yang terkumpul, berwujud hasil interviu atau pengamatan tentang permasalahan yang ada di lapangan.

Lokasi kajian dilakukan di salah satu sekolah SMA di kota Rantauprapat. Subjek kajian ialah 36 siswa yang berasal dari kelas XII. Instrumen dalam kajian ini ialah peneliti sendiri. Dimana pada kajian ini peneliti tersebut terjun kelapangan dan berinteraksi langsung dengan subyek penelitian baik itu dengan lingkungan, manusia seperti narasumber maupun non manusia yang berkaitan dalam penelitian (Alhamid \& Anufia, 2019). Sedangkan dalam mengumpulkan datanya peneliti menggunakan instrumen berupa angket, wawancara, observasi, dan dokumentasi.

Angket/kuesioner ialah sebuah instrumen yang digunakan untuk penelitian dan berisikan berupa daftar pertanyaan untuk partisipan agar mendapat data ataupun informasi terhadap suatu penelitian. Angket pada kajian ini ialah angket tertutup, dimana di dalam angket tersebut telah terdapat jawaban sehingga responden tidak memiliki kesempatan untuk memberikan jawaban nya sendiri. Angket yang diberikan kepada siswa adalah angket gaya belajar yang berupa pilihan ganda dengan jumlah pernyataan sebanyak 20 pernyataan. Dalam setiap pernyataan dikelompokkan menjadi tiga pilihan jawaban ialah $\mathrm{A}, \mathrm{B}$ dan $\mathrm{C}$. Dimana kelompok A untuk gaya belajar visual, kelompok B untuk gaya belajar auditori, serta C untuk gaya belajar kinestik. Angket bertujuan guna mencari tahu gaya belajar yang paling disukai murid selama proses pembelajaran daring.

Wawancara merupakan suatu kegiatan bertanya jawab yang dilangsungkan oleh dua ataupun banyak orang secara lisan yaitu pewawancara dengan narasumber. Dimana pewawancara sebagai pemberi pertanyaan dan narasumber sebagai sumber untuk memperoleh jawaban. Wawancara bertujuan untuk memperoleh informasi dalam bentuk tulisan atau rekaman yang berupa audio, visual ataupun audio visual.

Wawancara dilakukan secara langsung kepada beberapa guru untuk memperoleh data berupa informasi yang berpatokan pada jawaban dari hasil wawancara dengan peneliti. Jenis wawancara yang digunakan yaitu wawancara terstruktur, yang artinya pewawancara sudah mempersiapkan lebih dulu daftar pertanyaan yang akan ditanyakan, sehingga proses wawancara akan berjalan sesuai harapan dan 
mendapat hasil yang lebih efektif. Wawancara ini dilakukan untuk mengumpulkan data atau informasi tentang minat belajar siswa.

Observasi yang dilakukan untuk mengumpulkan seluruh data terkait permasalahan yang hendak dianalisis dengan mengamati secara langsung ke lokasi. Jenis pengobservasian pada kajian ini ialah observasi tidak terstruktur, yang artinya observasi yang dilakukan tanpa memiliki persiapan terlebih dahulu mengenai hal-hal apa yang akan diobservasi di lapangan.

Dokumentasi yaitu tehnik atau langkah dalam pengumpulan data melalui pengumpulan dokumen berupa file ataupun foto-foto yang dibutuhkan serta yang berkaitan dengan permasalahan yang hendak dikaji agar bisa dipahami secara rinci sehingga mampu memberikan bukti yang akurat dalam hal membuktikan permasalahan. Penggunaan dokumentasi bertujuan guna memperoleh suatu informasi beruba media tertulis ataupun berupa dokumen lainnya seperti gambaran umum yang ada di lembaga kependidikan, struktur organisasi tersebut, kondisi tenaga pendidi, serta murid, maupun foko lain yang belum diperoleh melalui prosedur angket, observasi, ataupun interviu.

Kajian ini mempergunakan data primer dan sekunder. Data primer ialah data dari sumber asli dan didapat melalui partisipan sebagai objek kajian guna mendapatkan informasi. Lalu, data sekunder merupakan data yang tersediakan dengan bermacam bentuk dan sudah terarsipkan, terpublikasi, maupun tidak terpublikasi, berupa laporan daftar hadir siswa yang mengikuti pembelajaran secara daring. Daftar siswa yang mengerjakan dan mengirimkan tugas.

\section{Teknik analasis data}

Teknik analisis data pada kajian ini, yaitu analisis Model Miles dan Huberman (1994), tersaji pada Gambar 1.

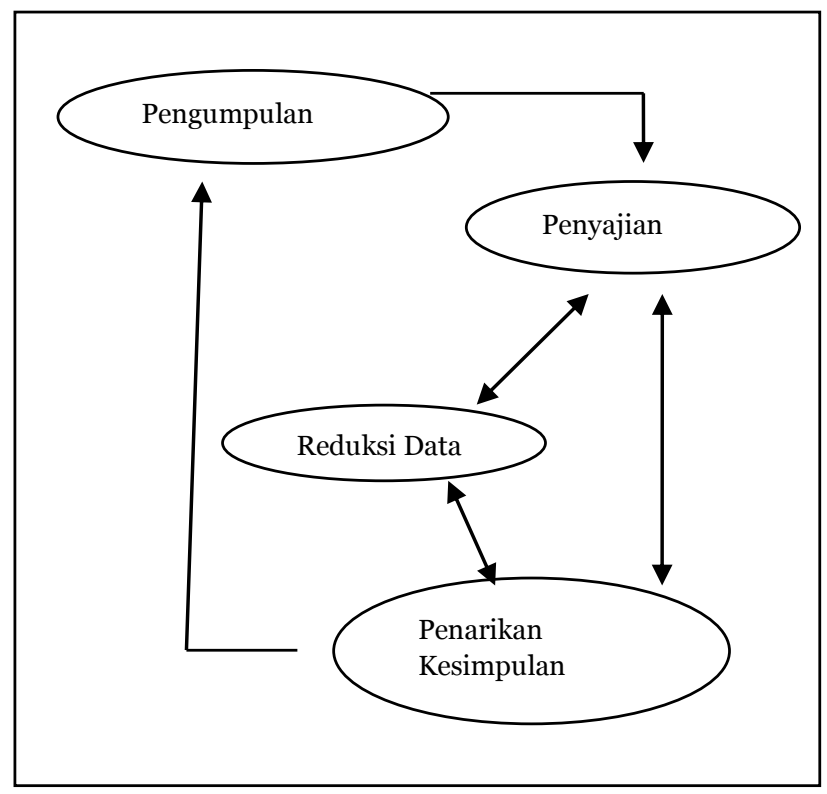

Gambar 1. Analisys Interactive Model Miles \& Huberman

\section{a. Pengumpulan Data}

Tahap mengumpulkan data yang perlu dilaksanakan, yaitu membuat rencana atau scenario dalam penelitian, menentukan latar atau tempat untuk melakukan penelitian, menentukan sumber data atau responden dalam penelitian, menentukan strategi, metode dalam mengumpulkan data, dan menyiapkan fasilitas dalam kajian. Data dikumpulkan mempergunakan cara mendapati sumber data secara langsung. Penting sekali menciptakan interaksi yang baik sumber data dengan peneliti pada saat melakukan proses pengumpulan data. Hal ini merujuk pada metode mengumpulkan data yang hendak dipergunakan yaitu angket, interviu, observasi, dan pendokumentasian.

Data hasil dari angket gaya belajar yang telah diperoleh dari responden akan di rekapitulasi berdasarkan jenis gaya belajarnya. Langkah langkah analisis datanya sebagai berikut.

1) Terdapat beberapa butir pernyataan mengenai gaya belajar terdiri atas gaya belajar visual, auditori, maupun kinestik. 
2) Hasil dari angket kemudian dianalisis dan dihitung skornya.

3) Penarikan kesimpulan mengenai gaya belajar yang paling disukai dilihat dari skor yang diperoleh dari ketiga gaya belajar tersebut.

4) Membuat rekapitulasi berupa hasil presentase gaya belajar yang paling disukai dan yang mampu meningkatkan minat belajar siswa.

Data dari hasil wawancara dilakukan untuk mengetahui lebih rinci mengenai gaya belajar yang bisa mengoptimalkan minat belajar murid saat pembelajaran daring.

\section{b. Penyajian Data/ Display}

Penyajian data ialah kegiatan dalam mengumpulkan informasi yang telah dilakukan, serta disusun sesuai dengan kategori yang dibutuhkan agar mudah untuk dipahami serta dianalisis berdasarkan tujuan yang di inginkan. Data yang didapat melalui hasil kajian kemudian tersajikan. Dengan menyajikan data dapat mempermudah peneliti dalam memahami apa saja yang terjadi dilapangan selama penelitian berlangsung. Selanjutnya penting sekali memiliki perencanaan kerja yang bersumber pada apa yang telah dipahami, dan dengan menyajikan data semoga para pengamat mudah dalam memahami apa yang telah disajikan. Dalam penyajian data bisa menggunakan narasi yaitu penyajian datanya dalam bentuk kalimat, dan bisa pula menggunakan tabel yaitu menyajikan data dalam bentuk angka-angka dan menggunakan grafik atau diagram yaitu menyajikan data dalam bentuk gambar-gambar.

\section{c. Reduksi Data (Data Reduksi)}

Reduksi data ialah kegiatan selama menentukan data, baik itu pengurangan data yang dianggap tidak relevan atau kurang perlu, atau menambahkan data yang dianggap masih kurang. Pada umumnya data yang diperoleh selama melangsungkan penelitian di lapangan jumlahnya cukup banyak Reduksi data memiliki arti menyederhanakan atau mengumpulkan data - data yang penting yang muncul dari datadata lapangan. Tahap reduksi data bisa dilakukan dengan cara sebagai berikut.

1) Menulis hasil interviu yang diperoleh selama penelitian.

2) Menyeleksi hasil wawancara yang dianggap perlu dan tidak perlu.

\section{d. Penarikan Kesimpulan}

Tahap terakhir dalam metode analisis data model Miles \& Huberman yaitu tahap verifikasi data atau pemeriksaan kebenaran data. Tujuannya untuk mencari penjelasan dari datadata yang telah dikumpulkan selama dilapangan untuk dibuat sebuah kesimpulan. Penarikan kesimpulan di peroleh dari data-data yang meliputi angket, wawancara, observasi dan dokumentasi. Verifikasi data ditujukan agar penilaian tentang kesesuaian data dengan arti yang terkandung lebih sesuai dan lebih obyektif.

\section{HASIL DAN PEMBAHASAN}

\section{a. Analisis Gaya Belajar}

Gaya belajar sangat perlu diperhatikan pada saat pembelajaran daring seperti saat ini. Meskipun saat ini pembelajaran dilangsungkan secara daring, namun kegiatan belajar mengajar harus tetap terlaksana dan mengacu pada minat serta kondisi siswa. Terlebih lagi sejak kegiatan pembelajaran sudah tidak bisa lagi dilakukan secara langsung, melainkan harus dengan jarak jauh. Sehingga siswa kurang bersemangat untuk belajar. Untuk itu penting sekali bagi seorang pendidik mengetahui apa gaya belajar yang paling disukai oleh siswa agar mereka mudah memperoleh dan mengolah informasi yang diberikan. Seseorang belum tentu menjadi lebih pandai meski telah diketahui gaya belajarnya, namun melalui mengetahui gaya belajar pada individu maka bisa mempermudah dalam 
menetapkan bagaimana metode belajar agar lebih efektif (Wahyuni, 2017).

Kajian ini mempunyai tujuan guna menganalisis gaya belajar yang paling disukai murid, serta yang mampu menumbuhkan minat belajar siswa pada saat pembelajaran daring diterapkan. Sedangkan gaya belajar yang dianalisis ialah gaya belajar visual, auditori, dan kinestik.

Siswa bergaya belajar visual akan cenderung efektif menyerap informasi melalui penglihatan. Murid dengan gaya belajar Auditory cenderung mudah menyerap informasi melalui pendengaran. Sedangkan siswa dengan gaya belajar kinestik dapat menyerap informasi dengan lebih mudah melalui praktek.

Berdasar hasil dari analisis data, terdapat presentasi hasil gaya belajar.

Tabel 1. Frekuensi gaya belajar siswa

\begin{tabular}{llcc}
\hline No & $\begin{array}{l}\text { Gaya } \\
\text { belajar }\end{array}$ & Frekuensi & $\begin{array}{l}\text { Presentase } \\
\text { (\%) }\end{array}$ \\
\hline $\mathbf{1}$ & Visual & 23 & 64 \\
2 & Auditori & 9 & 25 \\
3 & Kinestik & 4 & 11 \\
\hline
\end{tabular}

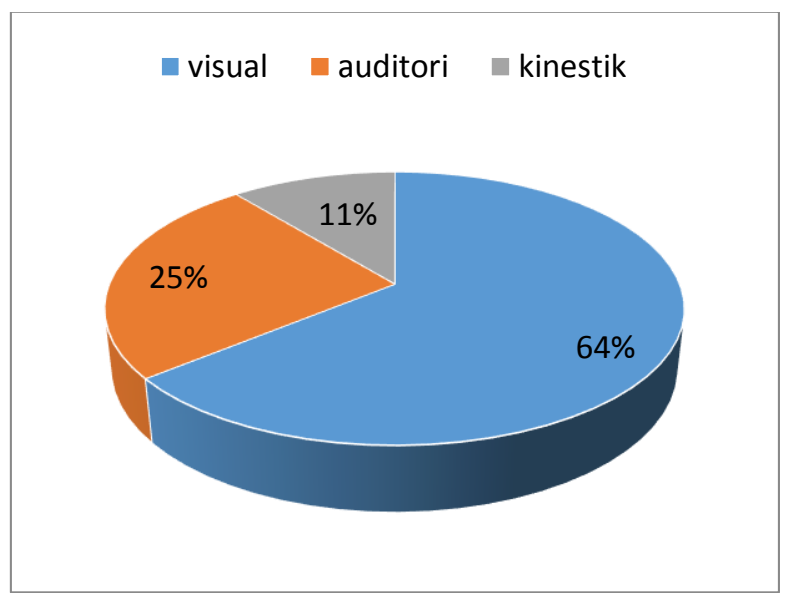

Gambar 2. Hasil presentase yang dikategorikan berdasarkan gaya belajar siswa.
Dari Gambar 2, terdapat 64\% dari banyak siswa cenderung bergaya belajar visual, sedangkan 25\% murid cenderung pada gaya belajar auditori dan $11 \%$ pada gaya belajar kinestik. Dengan demikian kecenderungan gaya belajar pada murid ketika proses belajar mengajar daring diterapkan yaitu gaya belajar visual.

\section{b. Minat Belajar}

Minat merupakan suatu pengamatan yang berisikan unsur-unsur perasaan seperti rasa senang, kecenderungan hati dan keinginan yang tidak disengaja dan sifatnya aktif untuk menerima sesuatu dari lingkungan (Andi, 2019). Minat dapat tumbuh sebab muncul simpati yang mendalam pada objek dan memunculkan rasa ingin tahu tentang suatu hal dan ingin mempelajari nya lebih lanjut.

Minat belajar merupakan kegemaran pada suatu materi pelajaran, selanjutnya akan memotivasi seseorang guna mempelajarinya, serta mendalami pelajaran itu. Kondisi saat ini dimana proses belajar mengajar harus dilangsungkan secara daring menyebab kan dampak pada menurunnya minat belajar siswa.

Metode guna meningkatkan minat belajar murid selama pembelajaran daring, yaitu menelaah metode pembelajaran yang disukai peserta didik tersebut. Melalui penelaahan akan metode pembelajaran peserta didik, maka akan mempermudah bagi siswa ataupun seorang guru untuk melangsungkan proses belajar mengajar. Sekadar menerapkan gaya belajar yang relevan mampu melahirkan minat belajar siswa, maka mereka kian memiliki semangat guna mempelajari suatu materi (Falah, n.d.).

Berdasar interview yang sudah dilaksanakan dengan beberapa tenaga pendidik, terdapat transkip interview sebagai berikut.

Penanya : Bagaimana proses belajar mengajar selama daring?

Jawaban : Pada saat daring biasanya saya mengajar menggunakan beberapa 
aplikasi berupa Google Classroom, Zoom dan WhatsApp.

Penanya : Metode apa yang diberikan pada saat akan memberikan pembelajaran?

Jawaban : Pada saat akan memberikan pembelajaran saya biasanya menggunakan ceramah secara tatap muka melalui aplikasi Zoom, kemudian dengan memberikan video pembelajaran dan photo tentang pembelajaran melalui Google Classroom dan WhatsApp.

Penanya : Bagaimana respon siswa mengenai metode pembelajaran yang diberikan?

Jawaban : Kurang nya minat belajar siswa pada pembelajaran daring ini membuat siswa malas untuk merespon pembelajaran.

Penanya : Apa tindakan yang di lakukan guna mengoptimalkan minat belajar siswa?

Jawaban : Hal yang dapat dilakukan yaitu dengan mengubah cara belajar supaya mereka tertarik untuk belajar seperti membuat video pembelajaran yang menarik dan lucu.

Penanya : Bagaimana respon siswa dengan video pembelajaran yang di berikan?

Jawaban : Alhamdulillah siswa lebih banyak merespon dan lebih semangat untuk mengikuti pembelajaran.

Penanya : Bagaimana dengan metode ceramah?

Jawaban : Pada saat sekarang ini dengan metode ceramah siswa tidak akan mampu menangkap informasi mengenai pembelajaran, dan itu meyebabkan minat belajar siswa menurun dan menjadikan siswa malas untuk belajar.

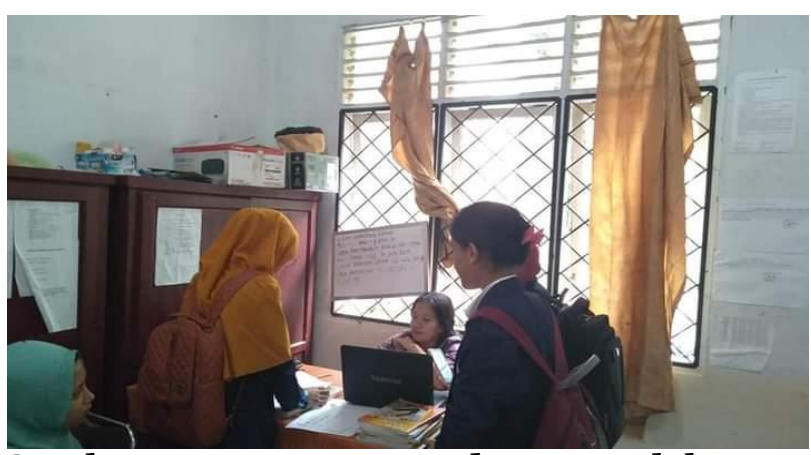

Gambar 3. Wawancara dengan salah satu guru

Wawancara dilaksanakan guna memperoleh data perihal metode seorang tenaga pendidik mengoptimalkan minat belajar murid selama kegiatan belajar mengajar daring. Transkip wawancara diatas menunjukkan bahwa gaya belajar siswa sangat dipengaruhi oleh minat belajar. Perihal ini diperkuat oleh hasil kajian (Kusuma \& Hamidah, 2019) yang mengungkapkan jika kegiatan belajar mengajar tidak akan terjadi tanpa adanya minat. Minat belajar siswa dapat dibangun jika proses pembelajaran sesuai dengan gaya belajar. Gaya belajar yang mampu meningkatkan minat belajar siswa selama pembelajaran daring yaitu gaya belajar visual. Hal ini memperkuat hasil angket yang memperlihatkan jika murid berkecenderungan bergaya belajar visual.

Hal ini dikarenakan selama proses pembelajaran daring ditetapkan siswa cenderung malas belajar jika guru menyampaikan pembelajaran dengan cara berceramah. Apalagi dengan metode praktek, kebanyakan murid enggan untuk mengerjakan tugas dari tenaga pendidik dengan alasan sulit untuk memahami pembelajaran yang disampaikan. Lain hal nya dengan gaya belajar visual, siswa lebih tertarik dan berminat untuk mengikuti proses belajar dengan melihat langsung pembelajaran dari tenaga pendidik. Biasanya pendidik memberikan tugas kepada murid dengan mengirim kan foto atau gambar, 
mengirim berupa video yang lucu dan menarik seperti power point dengan desain yang cantik dan lain sebagainya.

Hasil observasi yang dilakukan di sekolah, sebelum memulai pembelajaran secara daring guru terlebih dahulu memeriksa daftar hadir siswa melalui aplikasi yang digunakan untuk proses belajar mengajar. Aplikasi yang paling sering digunakan oleh guru untuk melaksanakan proses belajar mengajar yaitu WhatsApp Group. Karena lebih mudah digunakan serta lebih efektif untuk mengirim tugas kepada siswa dalam bentuk foto maupun video.

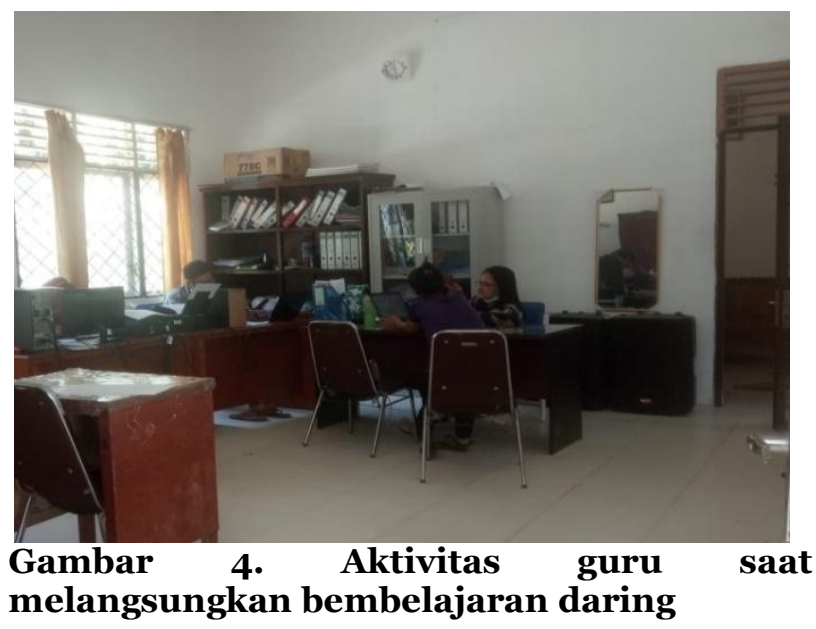

Dimasa pandemi ini pemerintah telah menetap kan kebijakan social distancing. Untuk itu siswa diharuskan belajar dari rumah. Perlu sekali bagi seorang pendidik mengetahui tipe gaya belajar siswanya agar dapat memaksimal kan proses pembelajaran.

Setiap tenaga pendidik hendaknya mampu menyesuaikan model pembelajaran dan penggunaan media dalam proses penyampaian materi supaya bisa meningkatkan minat belajar siswa untuk belajar selama pembelajaran daring diterapkan.

Gaya belajar sangat berpengaruh dalam meningkatkan minat belajar murid. Perihal ini diperkuat hasil kajian (Sarbini, 2016). Belajar dengan cara memberikan video animasi yang menarik adalah salah satu upaya dalam menumbuhkan minat belajar siswa pada saat pembelajaran daring berlangsung (Yunitasari ; Hanifah, 2020).

Murid bergaya belajar visual berkecenderungan belajar menggunakan indera penglihatan dibanding pendengaran. Seseorang bergaya belajar visual belajar menitikberatkan pada ketajaman penglihatan. Sehingga upaya yang dapat dilakukan untuk menumbuhkan minat siswa pada saat proses pembelajaran berlangsung yaitu guru mampu menyajikan suatu informasi melalui gambar, video ataupun hal-hal lainnya secara tertulis.

Karakteristik murid bergaya belajar visual, terdiri atas sangat rapi serta teratur, mementingkan penampilan, mengingat dengan gambar, sangat suka membaca, berbicara cepat, lebih suka seni daripada musik, selalu mencermati gerak bibir pada saat berbicara dengannya, cenderung suka peragaan ketimbang penjelasan secara lisan, teliti, pengeja yang baik.

Siswa bergaya belajar auditori paling mudah menangkap informasi yang mengandalkan pendengaran nya. Seseorang dengan bergaya belajar auditori ini menitikberatkan pendengaran sebagai media guna menelaah informasi maupun pengetahuan. Siswa dengan gaya belajar auditori biasanya sulit untuk menyerap pembelajaran secara langsung dalam bentuk tulisan, gambar dan lain sebagainya. Sehingga metode ceramah ataupun memberikan informasi melalui audio adalah upaya yang dapat diimplementasikan pendidik selama kegiatan belajar berlangsung.

Karakteristik murid bergaya belajar Ciri ciri auditori yaitu tidak suka kebisingan, pembicara yang fasih, suka belajar kelompok,menyukai musik, lebih mudah paham dengan mendengarkan, senang membaca dengan suara lantang, baik dalam berbicara maupun menyampaikan cerita, sangat bijak selama berbicara, serta belajar dengan mendengar maupun meningat. Siswa yang memiliki gaya belajar kinestik mengharuskan individu 
mendapatkan informasi harus dengan terlibat langsung. Sehingga belajar dengan cara praktek adalah upaya yang dapat diimplementasikan pendidik selama kegiatan belajar mengajar. Ciri ciri gaya belajar kinestik yaitu berbicara dengan pelan, banyak menggunakan isyarat tubuh, sangat suka berolahraga, mudah bosan (Mundayat, 2015).

Gaya belajar seseorang sangat mudah berubah tergantung dengan kebiasaan (Yulianci1 \& Nurjumiati1 ; Asriyadin1, 2020). Untuk itu bukan hal yang mustahil jika gaya belajar siswa akan terpengaruh oleh cara mengajar seorang guru. Siswa dengan gaya belajar visual bisa saja berubah menjadi auditori ataupun kinestik, begitu pula sebaliknya siswa dengan gaya belajar kinestik bisa saja berubah menjadi visual ataupun auditori. Hal ini diperkuat oleh penelitian dari (Halim, 2017) yang mengungkapakan bahwa adanya pengaruh strategi belajar dan gaya belajar siswa.

Seseorang akan mengalami perubahan dalam gaya belajarnya sesuai dengan perkembangan dan pengalaman yang diperolehnya selama proses belajar mengajar berlangsung. Namun sangatlah sulit untuk mengubah kebiasaan. Hal ini diperkuat oleh penelitian dari (Aldiyah, 2021) tentang adanya perubahan gaya belajar siswa. Untuk itu setiap tenaga pendidik hendaklah berusaha agar lebih kreatif dan mampu berinovasi untuk mengubah kebiasaan belajar siswa dan tidak hanya memberikan satu atau dua gaya belajar saja kepada siswa melainkan harus mengkombinasikan gaya belajar agar mempermudah siswa dalam menyerap pelajaran.

\section{KESIMPULAN}

Melalui hasil kajian yang sudah dilaksanakan, pembelajaran secara daring sangat berdampak pada menurunnya minat belajar murid. Karena peserta didik cenderung bosan dalam belajar, terlebih lagi disebab kan oleh beberapa hal seperti jam belajar yang tidak beraturan, pemberian tugas yang cukup banyak, koneksi jaringan buruk, serta sarana yang tidak mendukung. Oleh karena itu seorang guru diharuskan mampu melahirkan situasi pembelajaran daring yang semenarik mungkin sehingga dapat mendorong keinginan siswa dalam belajar serta menumbuhkan minat belajar murid itu. Metode yang bisa menumbukan minat belajar siswa yaitu dengan mengetahui gaya belajar yang paling disukai oleh siswa selama pembelajaran daring diterapkan. Gaya belajar sangat mempengaruhi minat belajar seseorang. Sebab dengan menggunakan gaya belajar yang relevan bakal mempermudah murid menyerap materi yang disampaikan pendidik.

Berdasar hasil analisis data menyatakan jika murid kelas XII yang terlibat proses belajar mengajar secara daring bercenderungan memiliki gaya belajar visual. Murid yang bercenderungan memliki gaya belajar visual berjumlah 64\%, auditori presentasenya sejumlah 25\%, dan kinestik sebanyak $11 \%$.

Gaya belajar sangat memengaruhi minat belajar siswa yang belajar secara daring dimasa pandemi ini. Hal ini dilihat dari daftar hadir siswa yang mengikuti pembelajaran dan keterlibatan siswa dalam hal tanya jawab mengenai pembelajaran, serta banyaknya murid yang bersedia mengerjakan tugas dari pendidik apabila proses pembelajaran mempergunakan gaya belajar visual. Dikarenakan murid lebih mudah memahami pembelajaran dengan melihat langsung tugas yang diberikan beserta cara pengerjaan nya yang dibuat dalam bentuk video dan didesain semenarik mungkin sehingga siswa tertarik untuk ikut serta dalam belajar.

\section{REFRENSI}

Agus Purwanto, Rudy Pramono, Masduki Asbari, Priyono Budi Santoso, Laksmi Mayesti Wijayanti, Choi Chi Hyun, R. S. P. (2020). Studi Eksploratif Dampak Pandemi COVID-19 Terhadap Proses Pembelajaran Online di Sekolah Dasar. EduPsyCouns, 2(1), 1-12.

Aldiyah, E. (2021). PERUBAHAN GAYA 
BELAJAR DI MASA PANDEMI COVID-19. jurnal ilmu pengetahuan: , 2(1), 8-16

Alhamid, T., \& Anufia, B. (2019). RESUME : INSTRUMEN PENGUMPULAN DATA. STAIN, sorong, 1-20.

Andi, A. (2019). PENGEMBANGAN MINAT BELAJAR DALAM PEMBELAJARAN. . JURNAL IDAARAH, 1(2), 205-215.

Asikin, I. (2017). Pengaruh Gaya Belajar dan Kecerdasan Emosional Terhadap Minat Belajar Peserta Didik Kelas X dan X1 SMK Bina Utama Depok. 4(1), 9-15.

Bire, A. L., Geradus, U., \& Bire, J. (2014). Effects of Visual, Auditorial, and Kinesthetic Learning Styles on Student Learning Achievement. Jurnal Kepaendidikan, 44(2), 168-174.

Falah, B. (n.d.). Pengaruh Gaya Belajar Siswa dan Minat Belajar. Euclid, 6(1), 25-34.

http://dx.doi.org/10.33603/e.v6i1.1226

Halim, A. (2017). PENGARUH STRATEGI PEMBELAJARAN DAN GAYA BELAJAR TERHADAP HASIL BELAJAR FISIKA. Jurnal Teknologi Pendidikan (JTP), 1O(1), 99.

Handarini, Oktafia Ika; Wulandari, S. S. (2020). Pembelajaran Daring Sebagai Upaya Study From Home (SFH) Selama Pandemi Covid 19. Jurnal Pendidikan Administrasi Perkantoran (JPAP ), 8(3), 496-503.

https://doi.org/10.1093/fampra/cmyo05

Hartanto, W. (2016). Penggunaan E-Learning sebagai Media Pembelajaran. Jurnal Pendidikan Ekonomi, 1O(1), 1-18.

Hayati, N. (2015). Hubungan Minat Belajar dengan Prestasi Belajar Matematika Siswa Kelas V SD Se-Gugus Wonokerto Turi Sleman Tahun Ajaran 2014/2015. Jurnal Pendidikan Guru Sekolah Dasar, 4(13), 110.

http://journal.student.uny.ac.id/ojs/index .php/pgsd/article/viewFile/1164/1037

khabiburrokhman, khamid abdul, ali yusuf faisal. (2020). Analisis Gaya Belajar Siswa melalui Media Pembelajaran Daring di Masa Pandemi Covid-19. 4(2), 211-219.

https://doi.org/https://doi.org/10.32332/ tapis.v4i2.2588

Kusuma, J. (2019). PERBANDNGAN HASIL BELAJAR MATEMATIKA DENGAN PENGGUNAAN PLATFORM WHATSAPP GROUP DAN WEBINAR ZOOM DALAM PEMBELAJARAN JARAK JAUH PADA MASA PANDEMI COVID 19. Jurnal Ilmiah Pendidikan Matematika, 5(1), 97-106.

Laana, D. L. (2021). PARENTS' SOLUTIONS IN INCREASING CHILDREN'S LEARNING INTEREST ONLINE DURING THE COVID-19 PANDEMIC. Inculco Journal of Christian Education, 1(1), 79-90.

Laana, D., \& Sondopen, D. (2018). Keterampilan Guru Pendidikan Agama Kristen Untuk Meningkatkan Minat Belajar Murid Di Kelas. Excelsis Deo: Jurnal Teologi, Misiologi, Dan Pendidikan, 2(2), 27-32. https://doi.org/10.51730/ed.v2i2.47

Mundayat, A. "Midas.” (2015). Ciri-ciri Gaya Belajar Visual, Auditori, dan Kinestetik. In Http://Gurusukses.Wordpress.Com/. http://www.dakwatuna.com/2012/03/26 /19578/pilihan-bagi-orang-orangterpilih/\#axzz3pN8ens2p

Papilaya, J. O., \& Huliselan, N. (2016). Identifikasi Gaya Belajar Mahasiswa. Jurnal Psikologi Undip, 15(1), 56-63. https://doi.org/10.14710/jpu.15.1.56-63

Rahmawati, N. K. (2017). Penerapan Model Pembelajaran Matematika Menggunakan Model Savi Dan Vak Pada Materi Himpunan Terhadap Prestasi Belajar Siswa. Delta: Jurnal Ilmiah Pendidikan Matematika, 5(2), 21-24. https://doi.org/10.31941/delta.v5i2.549

Sadikin, A., \& Hamidah, A. (2020). Pembelajaran Daring di Tengah Wabah Covid-19. Biodik, 6(2), 214-224. 
https://doi.org/10.22437/bio.v6i2.9759

Sarbini, S. P. (2016). PELAKSANAAN MODEL BELAJAR VAK UNTUK MENINGKATKAN MINAT BELAJAR MATA PELAJARAN PKn POKOK BAHASAN KEDAULATAN PADA SISWA KELAS VIII SEMESTER II DI SMP NEGERI 1 CINIRUKABUPATEN KUNINGANTAHUN

PELAJARAN2014/2015 Oleh. Pedagogi Jurnal Penelitian Pendidikan, o3(02), 109-121.

Sutriyani, W. (2020). Studi Pengaruh Daring Learning Terhadap Minat Dan Hasil Belajar Matematika Mahasiswa PGSD Era PAndemi Covid-19. Jurnal Pendidikan Dasar: Jurnal Tunas Nusantara, 2(1), 155-165.

Syarifudin, A. S. (2020). Impelementasi Pembelajaran Daring Untuk Meningkatkan Mutu Pendidikan Sebagai Dampak Diterapkannya Social Distancing. Jurnal Pendidikan Bahasa Dan Sastra Indonesia Metalingua, 5(1), 31-34. https://doi.org/10.21107/metalingua.v5i1. 7072

Wahyuni, Y. (2017). Identifikasi Gaya Belajar (Visual, Auditorial, Kinestetik) Mahasiswa Pendidikan Matematika Universitas Bung Hatta. Jurnal Penelitian Dan Pembelajaran Matematika, 1O(2), 128132.

https://doi.org/10.30870/ippm.v10i2.203 Z

Wiranti, D. A., \& Sutriyani, W. (2020). PENGARUH PEMBELAJARAN DARING MENGGUNAKAN HANACARAKA TERHADAP KEMAMPUAN MENULIS AKSARA JAWA DI SEKOLAH DASAR. Elementary, 8(2), 313-338.

http://journal.iainkudus.ac.id/index.php/ elementary\%oAPENGARUH

Yanti, Rida Adhari ; Nindisari, H. ; I. (2020). ANALISIS KEMAMPUAN PEMAHAMAN KONSEP MATEMATIS SISWA SMP
DENGAN PEMBELAJARAN DARING. Jurnal Inovasi Dan Riset Pendidikan Matematika, $\quad$ 245-255. https://doi.org/10.26877/imajiner.v2i5.6 517

Yulianci1, S., \& Nurjumiati1; Asriyadin1. (2020). Analisis Karakteristik Gaya Belajar VAK (Visual, Auditori, Kinestetik) Siswa Pada Pembelajaran Fisika. Jurnal Pendidikan MIPA, 1O(juni), 40-43. https://doi.org/https://doi.org/10.37630/ jpm.v10i1.328

Yunitasari, Ria ; Hanifah, U. (2020). Pengaruh Pembelajaran Daring Terhadap Minat Belajar Siswa Pada Masa Pandemi Covid19. EDUKATIF: JURNAL ILMU PENDIDIKAN Research \& Learning in Education, 2(1), 232-242. https://doi.org/https://doi.org/10.31004/ edukatif.v2i3.142 